\title{
Bird-flower interactions in the Macaronesian islands
}

\author{
Alfredo Valido*, Yoko L. Dupont and Jens M. Olesen
}

Department of Ecology and Genetics, University of Aarhus, Aarhus C, Denmark

*Correspondence: Alfredo Valido, Estación Biológica de Doñana (CSIC), Avda. $\mathrm{M}^{\mathrm{a}}$ Luisa s/n, Pabellón del Perú, E-41013 Sevilla, Spain. E-mail: avalido@ebd.csic.es

\section{ABSTRACT}

Aims Several bird-pollinated or ornithophilous flowers are present on the Macaronesian archipelagos, the Canary Islands and Madeira, but absent from nearby NW Africa and Europe. In Macaronesia, no specialist nectar-feeding birds are found, but several generalist passerine bird species visit flowers for nectar. Two hypotheses attempt to explain the origin and evolution of ornithophily in the Macaronesian flora. According to 'the island de novo hypothesis', bird-flowers evolved from mainland insect-pollinated ancestors after island colonization. Alternatively, ancestors of the ornithophilous Macaronesian plant species evolved bird-flowers before reaching the islands ('the relict hypothesis'). In this study we first compile information of Macaronesian bird-flower interactions from the literature and our own field observations. Secondly, we discuss the two hypotheses of origin of ornithophily in the light of evidence from recent molecular plant phylogenies, palaeontology, historical biogeography of the African avifauna and flora, and present-day ecological patterns.

Location Madeira and Canary Islands.

Results At least eleven endemic Macaronesian plant species from six genera have typical ornithophilous floral traits. These genera are: Canarina and Musschia (Campanulaceae), Isoplexis (Scrophulariaceae), Echium (Boraginaceae), Lotus (Fabaceae) and Lavatera (Malvaceae). These lineages have clear affinities to the Mediterranean region, except for Canarina whose closest relatives grow in East African mountains. Six generalist passerine bird species of Sylvia, Phylloscopus (Sylviidae), Serinus (Fringillidae) and Parus (Paridae) visit this flora for nectar.

Main conclusion We suggest that the origin and evolution of ornithophilous traits in these plant species took place mostly in mainland areas prior to island colonization. In Canarina and Lavatera, it is well supported that ornithophily is a relict condition, which originated in mainland areas possibly in association with specialist nectar-feeding birds. For the remaining plant species except Echium wildpretii bird floral traits probably also are a relict condition. These species may be derived from ancestors, which were visited by specialist nectar-feeding birds during geological periods when the Mediterranean and the Ethiopian vegetation were intermingled in mainland Africa. Probably, these mainland ancestors went extinct due to severe climatic fluctuations, while their Macaronesian descendants survived in 'refuge' on the islands. Finally, the island de novo hypothesis may explain the evolution of a mixed bird/insect-pollination system in the neoendemic red-flowered Echium wildpretii.

\section{Keywords}

Ornithophily, Canary Islands, Madeira, island evolution, generalist nectarfeeding passerine birds, Isoplexis, Lotus, Lavatera, Canarina, Echium, bird pollination syndrome, oceanic islands. 


\section{RESUMEN}

Objetivo En el presente estudio se aportan nuevos datos acerca de las interacciones entre aves y flores en los archipiélagos de Macaronesia (Islas Canarias y Madeira) con el fin de explicar el origen y la evolución de los carácteres ornitófilos presentes en algunas plantas endémicas de estas islas. Tanto la ausencia de este tipo de flora ornitófila en las áreas continentales cercanas, como la no existencia de aves nectarívoras especializadas en estas islas (inclusive en el pasado), hace que este fenómeno se haya considerado como un enigma biológico, aún sin resolver. Dos hipótesis principales han sido propuestas para explicar estos casos. Primero, que los carácteres florales evolucionaron recientemente en las islas a partir de ancestros que eran polinizados por insectos en el continente (hipótesis de novo). Alternativamente, que los ancestros que colonizaron estas islas ya presentaban caracteres ornitófilos previo a la colonización insular (hipótesis relictual). En el presente estudio, se discute ambas hipótesis utilizando información reciente acerca de las relaciones filogenéticas de estas plantas, así como datos paleontológicos, de la historia biogeográfica de la flora y avifauna de Africa, y de los patrones ecológicos actuales.

Localización Madeira y Canarias.

Resultados Los datos obtenidos muestran que al menos once plantas endémicas procedentes de seis líneas evolutivas independientes: especies de Canarina y Musschia (Campanulaceae), Isoplexis (Scrophulariaceae), Echium (Boraginaceae), Lotus (Fabaceae), y Lavatera (Malvaceae) presentan carácteres florales típicamente ornitófilos. Seis paseriformes generalistas: especies de Sylvia y Phylloscopus (Sylviidae), Serinus (Fringilliidae) y Parus (Paridae), son asiduos visitantes de estas flores para libar su néctar. Si excluimos a Canarina, la cual presenta sus relativos más cercanos en plantas de la flora etiópica, el resto de los taxones presentan clara afinidad con la flora del área mediterránea (donde actualmente no se encuentran ninguna especie de planta que podamos considerar como ornitófila, ni aves nectarívoras especializadas).

Conclusión Acorde a las evidencias presentadas, la principal conclusión obtenida en el presente estudio es que el origen y la evolución de los carácteres florales ornitófilos parece que tuvo lugar en el continente previo a la colonización insular. Para Canarina y Lavatera, parece evidente que la ornitofilia es una condición relictual que posiblemente se originó en asociación con aves especializadas en líbar néctar en el continente. Para el resto de especies con afinidad mediterránea, el origen de la ornitofilia es menos clara, pero las evidencias presentadas señalan igualmente hacia un origen continental, y que posiblemente tuvo lugar cuando elementos de la flora mediterránea estuvieron en contacto con la vegetación etiópica en el pasado. En este escenario, aves nectarívoras especializadas posiblemente visitaron asiduamente las flores de los ancestros de esta flora ornitófila macaronésica. Posteriormente, y como consecuencia de fluctuaciones climáticas severas en el continente, dichos elementos se extinguieron, y únicamente aquellos taxones que colonizaron y se establecieron en estas islas, sobrevivieron hasta nuestros días. Finalmente, la hipótesis de novo parece explicar mejor el caso de los tajinastes rojos (g. Echium), el cual es considerado como un neo-endemismo, y cuyas flores presentan rasgos mixtos de polinización por insectos y aves.

\section{Palabras clave}

Ornitofilia, Islas Canarias, Madeira, evolución insular, Paseriformes generalistas libadores de néctar, Isoplexis, Lotus, Lavatera, Canarina, Echium, síndromes de polinización por aves. 


\section{INTRODUCTION}

Thousands of species of flowering plants rely on birds as pollinators and about 50 families of birds are reported as flower visitors (Proctor et al., 1996; Renner, 1996). The largest diversity of specialist nectarivorous birds is found in tropical and subtropical regions (Proctor et al., 1996). In addition to these groups, several generalist birds occasionally include nectar in their diet. This behaviour is observed in Australia (e.g. Franklin \& Noske, 1999, 2000; Franklin, 1999), Africa (e.g. Oatley \& Skead, 1972; Pettet, 1977), Europe (e.g. Thake, 1980; Kay, 1985; Búrquez, 1989; Thiede, 1998), and Central and South America (e.g. Fisk \& Steen, 1976). Generally, opportunistic nectarivory is observed when preferred resources (insects, fruits and seeds) are in short supply and nectar from typical bird plant species is also abundant (e.g. during winter, early cold spring or dry seasons; Pettet, 1977; Thake, 1980; Búrquez, 1989; Franklin \& Noske, 1999).

Whereas opportunistic nectarivory by generalist passerines is considered casual in mainland ecosystems (but see Ford, 1985), it is a relatively frequent phenomenon on oceanic islands. Examples include Darwin Finches in Galápagos (Grant \& Grant, 1981), red-whiskered bulbul (Olesen et al., 1998), Madagascar fody (Safford \& Jones, 1998), Mauritius grey and olive white-eyes in Mauritius (Hansen et al., 2002), Japanese white-eye (Pimm \& Pimm, 1982; Lammers et al., 1989) and Hawaiian crow in the Hawaiian Islands (Cox, 1983), and several small passerines in Trinidad, Tobago (Feinsinger et al., 1982), and Canary Islands and Madeira (Vogel et al., 1984; Olesen, 1985; Valido et al., 2002; Olesen \& Valido, 2003a). The phenomenon may be related to certain characteristics of island biota. Compared with mainland areas, few species inhabit oceanic islands. Thus, interspecific competition is reduced. Some insular species respond to competitive release by increasing their abundance (density compensation; MacArthur et al., 1972). In lizards, nectarivory on islands may be a result of competitive release and density compensation, combined with a general shortage of arthropod food on islands (Olesen \& Valido, 2003b). A similar mechanism may explain nectarivory in generalist passerine birds (Olesen \& Valido, 2003a).

Since early last century, the association of birds and flowers in the Macaronesian islands has received interest (e.g. Porsch, 1924; Schmucker, 1936). Generalist passerine bird species, which regularly visit flowers for nectar include Sylvia atricapilla L., S. conspicillata Temminck, S. melanocephala Gmelin, and Phylloscopus collybita Vieillot (Sylviidae), Parus caeruleus L. (Paridae), and Serinus canarius L. (Fringillidae). The Palearctic P. collybita, P. caeruleus and Sylvia spp. are known to be insectivorous and/or frugivorous in mainland habitats (see references in Cramp, 1992; Cramp \& Perrins, 1994). The Macaronesian-endemic S. canarius is mostly granivorous (Martín \& Lorenzo, 2001). No specialized nectarivorous bird species are present in the Macaronesian islands, and no fossils indicate an earlier presence (Pieper, 1985; Tyrberg, 1998, 2003; H. Pieper \& J.C. Rando, pers. comm.). Nevertheless, a small group of endemic plant species show typical ornithophilous traits such as red-orange-yellow floral corolla, plenty of dilute nectar and absence of scent (Faegri \& Pijl, 1971). Typical ornithophilous plants are absent from the nearest mainland floras in S Europe and NW Africa.

Here, we review records of bird-flower interactions in the Macaronesian islands including new field observations. We discuss two hypotheses to explain origin and evolution of ornithophily in the Macaronesian flora. Floral traits in the birdpollinated plants could have evolved on the islands from mainland colonizers ('island de novo hypothesis'). Alternatively, these plants may originate from bird-pollinated mainland species ('relict hypothesis'). For the various lineages of Macaronesian ornithophilous plants, we discuss both hypotheses using four different approaches: molecular phylogenies, the fossil record, historical biogeography and ecological patterns.

\section{RESULTS}

At least six generalist passerine bird species visit flowers for nectar in 11 native plant species in Macaronesia (Table 1). The floral traits of most of these plants species includes typical ornithophilous traits. The three Canarian species of Isoplexis (Scrophulariaceae) and Canarina canariensis (Campanulaceae) are visited almost exclusively by birds. A few insects (solitary bees, e.g. Lasioglossum spp., Halictidae) too small to act as pollinators, have been observed visiting these large flowers. Furthermore, in secondary open forest, the Canarian-endemic lizard (Gallotia galloti Oudart, Lacertidae) drinks nectar from Isoplexis canariensis. Bumblebees often try to visit the Madeiran I. sceptrum. Their visits fail because the corolla becomes slippery and sticky from nectar oozing out of the corolla. The Madeiran Musschia wollastoni is visited by birds and insects. The extremely rare Lotus berthelotii (Fabaceae) certainly looks like an ornithophilous flower. However, apart from a few individuals of Lasioglossum spp., a Lycaenidae sp. and a few ants, no flower visitors have been observed. In Tenerife, Echium wildpretii ssp. wildpretii (Boraginaceae) is visited frequently by both insects, passerines and occasionally by lizards. On the other hand, only insects were observed visiting its sister subspecies E. W. ssp. trichosiphon in the sub-alpine scrubland on the island of La Palma. Only insects have been recorded visiting the Canarianendemic E. pininana in its natural habitats in La Palma. However, in New Zealand, where this species is introduced, the endemic Tui (Prosthemadera novaeseelandiae, Meliphagidae) takes its nectar. Furthermore, the Macaronesian flowervisiting birds (the six species mentioned above plus Passer hispaniolensis) forage for nectar in introduced plant species of Strelitzia, Hibiscus, Aloe, Nicotiana and Agave. These species originate from S Africa and S and C America where they are pollinated by sunbirds and hummingbirds.

\section{DISCUSSION}

We show that in the Macaronesian islands, six species of birds feed regularly on nectar in seven typical ornithophilous plant 
Table 1 Bird-plant interactions in the Macaronesian islands (M: Madeira; C: Canary). Scan: Serinus canarius; Pcoll: Phylloscopus collybita; Smel: Sylvia melanocephala; Satri: S. atricapilla; Scons: S. conspicillata; Pcae: Parus caeruleus. We also add some putatively ornithophil- ous plant species (Lotus spp.) according to Vogel et al. (1984), Olesen (1985), and personal observations. Furthermore, we include E. pininana because the Tui (Prosthemadera novaeseelandiae, Meliphagidae) was observed visiting plants introduced in New Zealand (pers. obs.). *Data from greenhouse plants. Sugar content of nectar is given as average sugar percentage (g sugar per 100 g nectar) \pm SD, sample size between brackets. References of bird-plant interactions: 1: Vogel et al. (1984); 2: Olesen (1985); 3: Trujillo (1992); 4: Valido et al. (2002) and Dupont et al. (2004a,b); 5: Olesen \& Valido (2003a); 6: present study

\begin{tabular}{|c|c|c|c|c|c|c|c|c|c|c|}
\hline & \multirow[b]{2}{*}{ Distribution and habitat } & \multicolumn{3}{|c|}{ Flower characteristics } & \multicolumn{6}{|l|}{ Birds } \\
\hline & & Colour & $\begin{array}{l}\text { Max. vol. } \\
\text { (1L) }\end{array}$ & \% Sugar & Scan & Pcoll & Smel & Satri & Scons & Pcae \\
\hline \multicolumn{11}{|l|}{ Boraginaceae } \\
\hline Echium decaisnei Webb & C; semidesert & White-blue & - & $10(1)$ & & 6 & 6 & & 3 & \\
\hline $\begin{array}{l}\text { Echium pininana } \\
\text { Webb \& Berthel. }\end{array}$ & C; laurel and pine forest & Light-blue & 1.4 & $26 \pm 3(20)$ & - & - & - & - & - & - \\
\hline Echium virescens DC. & $\mathrm{C}$; pine forest & Purple-blue & - & - & 6 & & & & & \\
\hline $\begin{array}{l}\text { Echium wildpretii wildpretii } \\
\text { Pearson ex. Hook. f. }\end{array}$ & $\begin{array}{l}\text { C; subalpine shrub } \\
\text { and pine forest }\end{array}$ & Red & 21 & $15 \pm 3.8(286)$ & 4 & 4 & & & & 4 \\
\hline $\begin{array}{l}\text { Echium wildpretii trichosiphon } \\
\text { (Svent.) Bramwell } \\
\text { Campanulaceae }\end{array}$ & C; subalpine shrub & Pink & - & $18.2 \pm 4.2(8)$ & - & - & - & - & - & - \\
\hline $\begin{array}{l}\text { Canarina canariensis } \\
\text { (L.) Vatke }\end{array}$ & C; laurel forest & Red-orange & 53 & $12.2 \pm 2.0(110)$ & & 1 & 2 & & 2 & \\
\hline $\begin{array}{l}\text { Musschia wollastonii Lowe } \\
\text { Crassulaceae }\end{array}$ & M; laurel forest & Purple-yellow & 149 & $12.5 \pm 1.2(15)$ & & & & 5 & & \\
\hline $\begin{array}{l}\text { Aeonium arboreum (L.) } \\
\text { Webb \& Berthel. }\end{array}$ & C; pine forest & Yellow & - & $20.7 \pm 4.9(30)$ & 6 & 6 & & & & \\
\hline \multicolumn{11}{|l|}{ Fabaceae } \\
\hline Lotus berthelotii Masf. & C; pine forest & Red & 49 & $24 \pm 15(18)$ & - & - & - & - & - & - \\
\hline Lotus eremiticus A. Santos & $\mathrm{C}$; pine forest & Orange & 14.5 & 48 & - & - & - & - & - & - \\
\hline $\begin{array}{l}\text { Lotus maculatus Breitf. } \\
\text { Malvaceae }\end{array}$ & C; xerophytic lowland & Yellow & 5.4 & 33 & - & - & - & - & - & - \\
\hline $\begin{array}{l}\text { Lavatera phoenicea Vent. } \\
\text { Scrophulariaceae }\end{array}$ & C; transition to laurel forest & Salmon & 112 & $24(1)$ & & 6 & & & & 6 \\
\hline $\begin{array}{l}\text { Isoplexis canariensis } \\
\text { (L.) J.W. Loudon }\end{array}$ & C; laurel and pine forest & Orange & & $32.3 \pm 10(28)$ & & 1 & 2 & 6 & & 6 \\
\hline $\begin{array}{l}\text { Isoplexis chalcantha } \\
\text { Svent. \& O’Shan. }\end{array}$ & C; laurel forest & Orange & 14 & $28.1 \pm 3(8)$ & & 6 & & & & \\
\hline $\begin{array}{l}\text { Isoplexis isabelliana* } \\
\text { (Webb \& Berthel.) Masf. }\end{array}$ & C; pine forest & Orange & & $29.1 \pm 12(28)$ & & 6 & 3 & & & \\
\hline Isoplexis sceptrum (L. fil.) & M; laurel forest & Orange & 81 & $40 \pm 15(10)$ & & & & 5 & & \\
\hline
\end{tabular}

species. Several other Macaronesian plant species have red, purple or orange flowers indicating potential bird pollination or perhaps a mixed bird/insect pollination system, e.g. the Canarian Scrophularia calliantha Webb \& Berthel. (Scrophulariaceae), Lotus pyranthus P. Pérez, L. berthelotii Masf., L. maculatus and L. eremiticus A. Santos, the Macaronesian Teucrium heterophyllum L'Her. (Lamiaceae), the Madeiran L. argyrodes R. P. Murray, and T. abutiloides L. Hér, and the Cape Verdean L. purpureus Webb and L. jacobaeus L. These species may be candidates for future observations of bird pollination. In addition, three plant species without evident ornithophilous floral traits are visited by Macaronesian birds (Echium decaisnei, E. virescens and Aeonium arboreum). We conclude that bird flowers and nectar feeding are relatively frequent phenomena in the Macaronesian islands compared with the nearest mainland. In the following, different nonexclusive lines of evidence are used to discuss the origin and evolution of these typical bird flowers.

\section{Phylogenetic evidence}

Molecular phylogenies now exist for the majority of Macaronesian plant genera containing bird-flower species: e.g. Böhle et al. (1996) for Echium, Carvalho \& Culham (1998) for Isoplexis, Fuertes-Aguilar et al. (2002) for Lavatera, Allan et al. (2004) for Lotus, and J.M. Olesen \& B.K. Ehlers (unpubl. data) for Canarina and Musschia spp. According to this information, ornithophilous floral traits of Lavatera phoenicea and Canarina canariensis could be plesiomorphic (Fuertes-Aguilar et al., 2002; J.M. Olesen \& B.K. Ehlers, unpubl. data). Lavatera 
phoenicea may be an example of a relict bird-pollinated species because it occupies a stem-basal lineage of the Lavatera-Malva complex. Furthermore, some floral traits (e.g. a specialized system for nectar delivery) are shared with the southern African sister plant species (Fuertes-Aguilar et al., 2002). Thus, L. phoenicea may belong to an old bird-pollinated clade, which may have been pollinated by African nectar birds. The continental origin of the ornithophilous characters appears more evident in $\mathrm{C}$. canariensis because their closest extant relatives C. eminii Ascherson ex Schweinf. and C. abyssinica Engler grow in E. African, and are visited by various sunbirds (J.M. Olesen \& B.K. Ehlers, unpubl. data). Canarina canariensis is sister to the two African species, thus ornithophilous traits in C. canariensis may be plesiomorphic traits shared with its African relatives in conjunction with specialist nectar-feeding birds in the mainland.

The origin of bird-pollination traits in the remaining plant taxa is less clear according to actual phylogenetic information. Ornithophily in the derived species of Isoplexis and Lotus may have either a mainland or a Macaronesian origin. Phylogenies suggest that the woody Isoplexis belongs to a clade which is derived from the continental herbaceous Digitalis (Carvalho \& Culham, 1998; C. Bräuchler, pers. comm., Fig. 1a). The closest relatives of Macaronesian Lotus spp. are Moroccan species (Allan et al., 2004, Fig. 1b). Ornithophilous Isoplexis and Lotus species seem to have evolved from lineages, which are insectpollinated and of a Mediterranean origin (Fig. 1a,b; see also
Carine et al., 2004). However, in these cases the origin of ornithophily remains obscure and an interpretation of evolutionary patterns is blurred by incomplete knowledge of potential plant-pollinator interactions in the past. For instance, bee-pollinated Digitalis species introduced to NW America are frequently visited by hummingbirds (David, 1996; C. Barr, pers. comm.) and by sunbirds in South Africa (Fry et al., 2000; Y. Wijk, pers. comm.). Isoplexis spp. have hexosedominated nectar, whereas studied Digitalis spp. have sucroserich nectar (Best \& Bierzychudek, 1982; Dupont et al., 2004a). Specialist nectarivorous birds can assimilate sucrose, whereas some opportunistic nectar feeders can only digest hexoses (Nicolson, 2002). Thus, sucrose-tolerant African nectar-feeding birds may have visited ancestors of the Digitalis-Isoplexis lineage (see below).

Finally, the molecular phylogeny of Echium (Böhle et al., 1996) combined with observations of flower visitors (Dupont \& Skov, 2004) suggest that the bird-visited Echium wildpretii and E. decaisnei evolved within a mainly entomophilous lineage. Moreover, ornithophily most likely evolved after colonization of the Canary Islands (Fig. 1c). Thus, in the neo-endemic Echium wildpretii bird pollination and ornithophilous traits evolved de novo on the islands, possibly in association with resident nectar-drinking passerines. However, additional phylogenetic information will be necessary to resolve these issues because limited utility of these phylogenetic studies alone. For example, for some clades it is required to

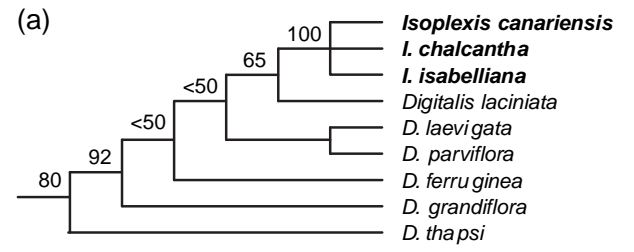

(b)

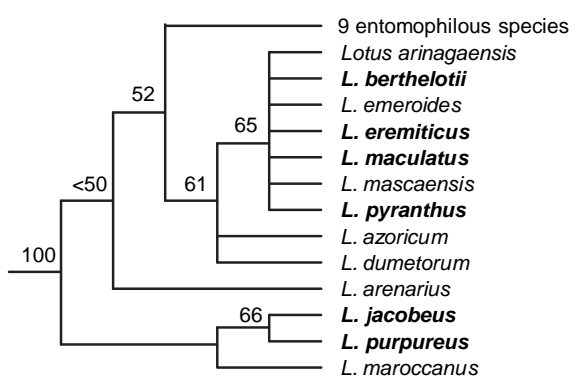

(c)

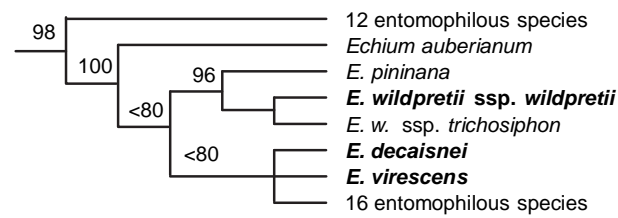

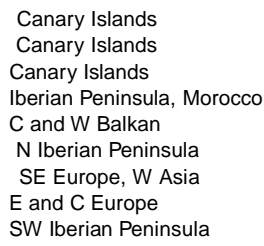

Canary Islands

Canary Islands

Canary Islands

Iberian Peninsula, Morocco

$\mathrm{C}$ and W Balkan

$N$ Iberian Peninsula

SE Europe, W Asia

$E$ and $C$ Europe

SW Iberian Peninsula

Canary Islands and Morocco
Canary Islands
Canary Islands
Canary Islands
Canary Illands
Canary Islands
Canary Islands
Canary Islands
Azores
Canary Islands
Canary Islands
Cape Verde Islands
Cape Verde Islands
Morocco
Europe and N Africa
Canary Islands
Canary Islands
Canary Islands
Canary Islands
Canary Islands
Canary Islands
Canary Islands, Madeira, Cape Verde

Figure 1 Parsimony trees of three plant lineages containing Macaronesian bird-flower species. Trees have been redrawn from (a) Isoplexis/Digitalis (Carvalho \& Culham, 1998), (b) Lotus (Allan et al., 2004), and (c) Echium (Böhle et al., 1996). Ornithophilous and putatively ornithophilous species are in bold face, the remaining species are entomophilous. Geographical distribution of the plants is indicated to the right. 
include all the putative relatives (in particular the positions of close relatives of Macaronesian species), and for others, new studies are needed using high-resolution molecular markers to increase phylogenetic resolution and bootstraps values (Allan et al., 2004; Andrus et al., 2004).

\section{Fossil evidence}

Specialist flower visitors are important as selective factors on floral morphology. In continental Africa, specialist nectarivorous birds belong to the Promeropidae, Zosteropidae and especially the Nectariniidae. None of these families have Macaronesian representatives, and presently the closest locality of specialist nectarivorous birds is the Acacia steppe in Senegal (Moreau, 1966; Fry et al., 2000). The Macaronesian and NW African fossil small-bird fauna is virtually unknown (Pieper, 1985; Tyrberg, 1998, 2003; Rando, 2003). Evidence exists that some Canarian passerine species have gone extinct (Emberiza alcoveri, Rando et al., 1999). On the other hand, some nectarfeeding bird species repeatedly colonized African offshore islands (e.g. Comoros Islands), which are more isolated than the Canary Islands. Thus, we cannot completely exclude the possibility that specialist nectar-drinking birds were present in Macaronesia in the past. If so, they may have influenced floral evolution (Vogel et al., 1984).

\section{Historical biogeography of African flora and avifauna}

Although the fossil record is incomplete, indirect evidence tentatively suggests that specialist nectarivorous birds never inhabited the Macaronesian islands. The NW African bird fauna, like that of Madeira and Canary Islands, has a Palearctic affinity, whereas the NE African avifauna (bounded by the Nile) has an Ethiopian affinity (Moreau, 1966). Small forest passerines of the Ethiopian avifauna have never been found as far west as NW Africa (Moreau, 1966; Tyrberg, 1998, 2003; Fry et al., 2000). At least since the Pliocene, birds of W Africa have been separated from the Ethiopian avifauna by the Sahara desert (Blondel \& Mourer-Chauviré, 1998). Moreover, although some Macaronesian islands have a mid-Miocene origin, the main woody species of the laurel and pine forests (Wang et al., 1999; Arroyo-García et al., 2001), and associated fauna and flora (Brunton \& Hurst, 1998; Sturmbauer et al., 1998; Caujapé-Castells et al., 1999; Emerson et al., 2000a,b; Helfgott et al., 2000; Pestano et al., 2003), may not have been present until geologically recently. Thus, we find it unlikely that specialist nectar-feeding birds were present in Macaronesia in the past.

However, the expansion of a Mediterranean vegetation southwards during cool periods (possibly as far south as to Lake Chad; Moreau, 1966), may have brought sunbirds, whiteeyes and/or sugarbirds into contact with the Mediterranean flora in N Africa. This flora does not contain bird flower elements, and thus ornithophily becomes a 'new' condition derived from entomophily. Sunbirds and white-eyes forage opportunistically and often explore new resources of food, e.g. the nectar of numerous exotic plants (Vogel, 1954; Fry et al., 2000). It is plausible that these birds visited the ancestors of the Macaronesian ornithophilous plants, exerting a phenotypic selection on floral traits. A similar scenario of intermingling floras and hummingbirds is described by Grant (1994) to explain the origin of ornithophily in North America. Thus, for extended timespans, ancestors of the Macaronesian bird flowers may have lived in contact with sunbirds and other nectar-feeding birds from continental Africa.

\section{Associations with generalist passerines in islands}

If specialist nectar birds never inhabited the Macaronesian islands, and ornithophily did evolve de novo on the islands, ornithophilous traits might have evolved as a response to resident generalist nectar-feeding birds. This could be the case for the neo-endemic E. wildpretii. In contrast to mainland regions, directional selection in response to generalist pollinators may be possible in island environments. Low species numbers, density compensation and the use of nectar as an alternative food resource, may make generalized passerine birds important pollinators exerting selective pressure on some plant species on islands (Olesen et al., 2002). If these birds are the only effective pollinators in the insular environment, floral evolution may occur in response to these birds, even within a generalist pollination regime ('most effective pollinator principle', Stebbins, 1970). On the other hand, there is no clear evidence that Phylloscopus collybita or other generalist passerines induce a selective pressure to drive evolution of ornithophilous traits. For instance, these birds also takes nectar from flowers, which are not typically ornithophilous.

\section{CONCLUDING REMARKS}

According to the available evidence, we suggest that the origin and evolution of ornithophilous traits in the Macaronesian bird flowers mostly took place in continental Africa prior to colonization of the islands. However, no single hypothesis can explain all cases of ornithophily in Macaronesia as each plant group have a unique biogeographic and evolutionary history.

For Lavatera, ornithophily may be a relict condition, which evolved in association with African nectarivorous birds (Fuertes-Aguilar et al., 2002). During glaciations and dry periods the relative mainland plant species disappeared allowing these climatic changes during Quaternary (Quézel, 1978), and only relative survived in island refuge (Tenerife). A similar scenario may apply to Canarina canariensis, whose closest relatives are still extant. The mainland relatives became isolated in mountain 'island' refuges in E Africa, where they are pollinated by sunbirds.

For Isoplexis, the most plausible explanation is that the Macaronesian species are derived from an ancestor in the Isoplexis-Digitalis clade, which may have been visited by specialist nectar-feeding birds in continental Africa. The 
present distribution of red-flowered species of Digitalis around the Mediterranean Basin, outside the distribution range of specialist nectarivorous birds, may explain why only insects visit these flowers today. Similarly, ornithophily may have evolved in African continental ancestors of Lotus. However, more information about the pollination biology of the continental African species is needed to explain the occurrence of ornithophilous traits in this clade.

Finally, ornithophily may have evolved by island de novo evolution in Echium wildpretii. The association with generalist birds in an insular setting may have induced directional selection, even in a generalist pollination regime. However, there is no evidence that island generalistic passerines are sufficient selective agents acting on floral variation and driving evolution of a set of bird pollination-related traits.

\section{ACKNOWLEDGMENTS}

For useful comments and discussion we thank Tonyo Alcover, Charleen Barr, Dennis M. Hansen, Cecile Mourer, Harald Pieper, Juan Carlos Rando, Jean-Pierre Suc, Tommy Tyrberg, and Yvette van Wijk. Javier Francisco-Ortega and an anonymous reviewer provided helpful suggestions on an earlier draft of this manuscript. We are also grateful to Bodil Ehlers for access to unpublished plant phylogeny data. This project was financed by a Marie Curie grant, European Union, MCFI-20001995 (to AV), the Danish Natural Science Research Council (to JMO), and the Villum Kann Rasmussen Foundation (to YLD).

\section{REFERENCES}

Allan, G.J., Francisco-Ortega, J., Santos-Guerra, A., Boerner, E. \& Zimmer, E.A. (2004) Molecular phylogenetic evidence for the geographic origin and classification of Canary Island Lotus (Fabaceae: Loteae). Molecular Phylogenetic and Evolution (in press).

Andrus, N., Trusty, J., Santos-Guerra, A., Jansen, R.K. \& Francisco-Ortega, J. (2004) Using molecular phylogenies to test phytogeographical links between East/South Africa Southern Arabia and the Macaronesian islands - a review, and the case of Vierea and Pulicaria section Vieraeopsis (Asteraceae). Taxon (in press).

Arroyo-García, R., Martínez-Zapater, J.M., Fernández, J.A. \& Álvarez-Arbesú, R. (2001) AFLP evaluation of genetic similarity among laurel populations (Laurus L.). Euphytica, 122, 155-164.

Best, L.S. \& Bierzychudek, P. (1982) Pollinator foraging on Foxglove (Digitalis purpurea): a test of a new model. Evolution, 36, 70-79.

Blondel, J. \& Mourer-Chauviré, C. (1998) Evolution and history of the western Palearctic avifauna. Trends in Ecology and Evolution, 13, 488-492.

Böhle, U.-R., Hilger, H.H. \& Martin, W.F. (1996) Island colonization and evolution of the insular woody habit in Echium L. (Boraginaceae). Proceedings of the National Academy of Sciences of the USA, 93, 11740-11745.
Brunton, C.F.A. \& Hurst, G.D.D. (1998) Mitochondrial DNA phylogeny of Brimstone butterflies (genus Gonopteryx) from the Canary Islands and Madeira. Biological Journal of the Linnean Society, 63, 69-79.

Búrquez, A. (1989) Blue tits, Parus caeruleus, as pollinators of the crown imperial, Fritillaria imperialis, in Britain. Oikos, 55, 335-340.

Carine, M.A., Russell, S.J., Santos-Guerra, A. \& FranciscoOrtega, J. (2004) Relationships of the Macaronesian and Mediterranean floras: molecular evidence for multiple colonizations into Macaronesia and back-colonization of the continent in Convolvulus L. (Convolvulaceae). American Journal of Botany (in press).

Carvalho, J.A. \& Culham, A. (1998) Conservation status and phylogenetics of Isoplexis (Lindl.) Benth. (Scrophulariaceae): an endemic Macaronesian genus. Bulletin do Museo Municipal do Funchal, 5, 109-127.

Caujapé-Castells, J., Jansen, R.K., Pedrola-Monfort, J. \& Membrives, N. (1999) Chloroplast DNA restriction site phylogeny of the genus Androcymbium (Colchicaceae). Systematic Botany, 24, 581-597.

Cox, P.A. (1983) Extinction of the Hawaiian avifauna resulted in a change of pollinators for the ieie, Freycinetia arborea. Oikos, 41, 195-199.

Cramp, S. (1992) Handbook of the birds of Europe, the Middle East and North Africa, Vol. VI. Warblers. Oxford University Press, Oxford.

Cramp, S. \& Perrins, C.M. (1994) Handbook of the birds of Europe, the Midle East and North Africa, Vol. VIII. Oxford University Press, Oxford.

David, S. (1996) Wildlife in my backyard: Part 3a: attracting hummingbirds. Blue Bill, 43, 15-24.

Dupont, Y.L. \& Skov, C. (2004) Influence of geographical distribution and floral traits on species richness of bees (Hymenoptera: Apoidea) visiting Echium species (Boraginaceae) in the Canary Islands. International Journal of Plant Sciences, 118, 301-311.

Dupont, Y.L., Hansen, D.M., Rasmussen, J.T. \& Olesen, J.M. (2004a) Evolutionary changes in nectar sugar composition associated with switches between bird and insect pollination: the Canarian bird-flower element revisited. Functional Ecology (in press).

Dupont, Y.L., Hansen, D.M., Valido, A. \& Olesen, J.M. (2004b) Impact of introduced honey bees on native pollination interactions of the endemic Echium wildpretii (Boraginaceae) on Tenerife, Canary Islands. Biological Conservation, 118, 301-311.

Emerson, B.C., Oromí, P. \& Hewitt, G.M. (2000a) Colonization and diversification of the species Brachyderes rugatus (Coleoptera) on the Canary Islands: evidence from mitochondrial DNA CoII gene sequences. Evolution, 54, 911-923.

Emerson, B.C., Oromí, P. \& Hewitt, G.M. (2000b) Tracking colonization and diversification of insect lineages on islands: mitochondrial DNA phylogeography of Tarphius canariensis (Coleoptera: Colydiidae) on the Canary Islands. Proceedings of the Royal Society of London. Series B, 267, 2199-2205. 
Faegri, K \& Pijl, L.V.D. (1971) The principles of pollination ecology. Pergamon Press, Oxford.

Feinsinger, P., Wolfe, J.A. \& Swarm, L.A. (1982) Island ecology: reduced hummingbird diversity and the biology of plants, Trinidad and Tobago, West Indies. Ecology, 63, 494-506.

Fisk, L.H. \& Steen, D.A. (1976) Additional exploiters of nectar. Condor, 78, 269-271.

Ford, H.A. (1985) Nectarivory and pollination by birds in southern Australia and Europe. Oikos, 44, 127-131.

Franklin, D.C. (1999) Opportunistic nectarivory: an annual dry season phenomenon among birds in monsoonal Northern Australia. Emu, 99, 135-141.

Franklin, D.C. \& Noske, R.A. (1999) Birds and nectar in a monsoonal woodland: correlations at three spatio-temporal scales. Emu, 99, 15-28.

Franklin, D.C. \& Noske, R.A. (2000) Nectar sources used by birds in monsoonal north-western Australia: a regional survey. Australian Journal of Botany, 48, 461-474.

Fry, C.H., Keith, S. \& Urban, E.K. (eds) (2000). The birds of Africa, Vol. VI. Academic Press, London.

Fuertes-Aguilar, J., Ray, M.F., Francisco-Ortega, J., SantosGuerra, A. \& Janzen, R.K. (2002) Molecular evidence from chloroplast and nuclear markers for multiple colonizations of Lavatera (Malvaceae) in the Canary Islands. Systematic Botany, 27, 74-83.

Grant, V. (1994) Historical development of ornithophily in the western North American flora. Proceedings of the National Academy of Science of the USA, 91, 10407-10411.

Grant, B.R. \& Grant, P.R. (1981) Exploitation of Opuntia cactus by birds on the Galápagos. Oecologia, 49, 179-187.

Hansen, D.M., Olesen, J.M. \& Jones, C.G. (2002) Tree, birds and bees in Mauritius: exploitative competition between introduced honey bees and endemic nectarivorous birds? Journal of Biogeography, 29, 721-734.

Helfgott, D.M., Francisco-Ortega, J., Santos-Guerra, A., Jansen, R.K. \& Simpson, B.B. (2000) Biogeography and breeding system evolution of the woody Bencomia alliance (Rosaceae) in Macaronesia based on ITS sequence data. Systematic Botany, 25, 82-97.

Kay, Q.O.N. (1985) Nectar from willow catkins as a food source for blue tits. Bird Study, 32, 40-44.

Lammers, T.G., Weller, S.G. \& Sakai, A.K. (1989) Japanese white-eye, an introduced passerine, visits the flowers of Clermontia arborescens, an endemic Hawaiian lobelioid. Pacific Science, 41, 74-78.

MacArthur, R.H., Diamond, J.M. \& Karr, J.R. (1972) Density compensation in island faunas. Ecology, 53, 330-342.

Martín, A. \& Lorenzo, J.A. (2001) Aves del Archipiélago Canario. F. Lemus, La Laguna, S/C Tenerife, Canary Islands.

Moreau, R.E. (1966) The bird faunas of Africa and its islands. Academic Press, London \& New York.

Nicolson, S.W. (2002) Pollination by passerine birds: why are the nectars so dilute? Comparative Biochemistry and Physiology B, 131, 645-652.

Oatley, T.B. \& Skead, D.M. (1972) Nectar feeding by South African birds. The Lammergeyer, 15, 65-73.
Olesen, J.M. (1985) The Macaronesian bird-flower element and its relation to bird and bee opportunists. Botanical Journal of the Linnean Society, 91, 395-414.

Olesen, J.M. \& Valido, A. (2003a) Bird pollination in Madeira Island. Ardeola, 50, 65-67.

Olesen, J.M. \& Valido, A. (2003b) Lizards as pollinators and seed dispersers: an island phenomenon. Trends in Ecology and Evolution, 18, 177-181.

Olesen, J.M., Rønsted, N., Tolderlund, U., Cornett, C., Mølgaard, P., Madsen, J., Jones, C.J. \& Olsen, C.E. (1998) Mauritian red nectar remains a mystery. Nature, 393, 529.

Olesen, J.M., Eskildsen, L.I. \& Venkatasamy, S. (2002) Invasion of pollination networks on oceanic islands: importance of invader complexes and endemic super generalists. Diversity and Distributions, 8, 181-192.

Pestano, J., Brown, R.P., Suárez, N.M., Benzal, J. \& Fajardo, S. (2003) Intraspecific evolution of Canary Island Plecotine bats, based on mtDNA sequences. Heredity, 90, 302-307.

Pettet, A. (1977) Seasonal changes in nectar-feeding by birds at Zaria, Nigeria. The Ibis, 119, 291-308.

Pieper, H. (1985). The fossil land birds of Madeira and Porto Santo. Bocagiana, 88, 1-6.

Pimm, S.L. \& Pimm, J.W. (1982) Resource use, competition, and resource availability in Hawaiian honeycreepers. Ecology, 63, 1468-1480.

Porsch, O. (1924) Vogelblumenstudien I. Jahrbuch für Wissenschafliche Botanik, 63, 553-706.

Proctor, M., Yeo, P. \& Lack, A. (1996) The natural history of pollination. Harper Collins, London.

Quézel, P. (1978) Analysis of the flora of Mediterranean and Saharan Africa. Annals of the Missouri Botanical Garden, 65, 479-534.

Rando, J.C. (2003) Protagonistas de una catástrofe silenciosa. Los vertebrados extintos de Canarias. El Indiferente, La Orotava, 14, 4-15.

Rando, J.C., López, M. \& Seguí, B. (1999) A new species of extinct flightless passerine (Emberizidae: Emberiza) from the Canary Islands. The Condor, 101, 1-13.

Renner, S.S. (1996) Effects of habitat fragmentation on plant pollinator interactions in the tropics. Dynamics of tropical communities (ed. by D.M. Newbery, H.H.T. Prins and N.D. Brown), pp. 339-360. Blackwell, Oxford.

Safford, R.J. \& Jones, C.G. (1998) Strategies for land-bird conservation on Mauritius. Conservation Biology, 12, 169176.

Schmucker, T. (1936) Über die blüten von Canarina Campanula. Berichte der Deutschen Botanischen Gesekschaft, 54, 230-239.

Stebbins, G.L. (1970) Adaptive radiation of reproductive characteristics in angiosperms, I: pollination mechanisms. Annual Review of Ecology and Systematics, 1, 307-326.

Sturmbauer, C., Berger, B., Dallinger, R. \& Föger, M. (1998) Mitochondrial phylogeny of the genus Regulus and implications on the evolution of breeding behavior in Sylvioid songbirds. Molecular Phylogenetics and Evolution, 10, 144149. 
Thake, M.A. (1980) Nectar: a supplementary food resource for wintering Chiffchaffs (Phylloscopus collybita). Rivista italiana Ornitologia, Milano, 50, 167-168.

Thiede, W.V. (1998) Pollentransport im Vogelgefieder und Vogelblütigkeit. Beiträge zur Gefiederkunde und Morphologie der Vögel, 5, 46-60.

Trujillo, O. (1992) Los Sílvidos en Gran Canaria. Contribución al estudio de la avifauna canaria. Excmo. Cabildo Insular de Gran Canaria, Las Palmas de Gran Canaria, Canary Islands.

Tyrberg, T. (1998) Pleistocene birds of Palearctic: a catalogue. Publication of the Nuttall Ornihological Club 27, Cambridge, MA.

Tyrberg, T. (2003) Pleistocene birds of the Palearctic. Stand on 8 October 2003. http://w1.115.telia.com/ u11502098/ pleistocene.pdf
Valido, A., Dupont, Y.L. \& Hansen, D.M. (2002) Native birds and insects, and introduced honey bees visiting Echium wildpretii (Boraginaceae) in the Canary Islands. Acta Oecologica, 23, 413-419.

Vogel, S. (1954) Blütenbiologische Typen als Elemente der Sippengliederung. Botanische Studien, 1, 1-338.

Vogel, S., Westerkamp, C., Thiel, B. \& Gessner, K. (1984) Ornitophilie auf den Canarischen Inseln. Plant Systematics and Evolution, 146, 225-248.

Wang, X., Tsumura, Y., Yoshimaru, H., Nagasaka, K. \& Szmidt, A.E. (1999) Phylogenetic relationships of Eurasian pines (Pinus, Pinaceae) based on chloroplast rbcL, matK, rpl20-rps18 spacer, and trnV intron sequences. American Journal of Botany, 18, 1742-1753.

\section{BIOSKETCHES}

Alfredo Valido is in a postdoctoral position at the Department of Ecology and Genetics, University of Aarhus. His research interests are centred on the ecological and evolutionary importance of lizards and birds in plant-animal interactions (pollination and seed dispersal) on islands.

Jens M. Olesen is an associate professor. His research interest is pollination ecology and island biology.

Yoko L. Dupont is in a postdoctoral position at the Department of Ecology and Genetics, University of Aarhus. Her research interests are plant-animal interactions and island biology, in particular pollination ecology. 